\title{
Heat-Affected Zone of Plasma of Laser Cut Materials
}

Dana Stancekova, Jan Semcer, Michal Sajgalik, Miroslav Janota University of Zilina, Faculty of Mechanical Engineering, Univerzitna 1, 010 26, Zilina, Slovak Republic dana.stancekova@fstroj.uniza.sk,jan.semcer@fstroj.uniza.sk,michal.sajgalik@fstroj.uniza.sk

Permanent evolution of new high-strength and difficult-to-machine materials as well as production of precise and shaped products have made the engineering practice to advance towards development of technologies to allow such materials to be machined without major difficulties. In such cases, advanced machining technologies are gaining ground whose principle is based on application of physical, or combined physical and mechanical methods of forceless material removal rather than mechanical work such as conventional cutting operations. In most cases, such methods involve conversion of the energy supplied to heat which, more or less, affects the base material being machined. The most frequent technologies of this kind include machining by cutting using a plasma beam or a laser beam. The plasma beam machining and laser beam machining are both based on melting the material at extremely high temperatures. Such extremely high temperatures cause formation on an area in the base material where the structure of the material is changed by the heat down to various depths. The objective of the experiments described in this paper is to determine the size of the heat-affected zone and to identify the changes in the structure of selected types of material and their effects on further machining.

Keywords: plasma cutting, laser cutting, heat-affected zone, structure of base material

\section{Acknowledgement}

The article was made under support grant project VEGA 1/0773/12 Implementation of technical ceramic material research to increase the innovation of hybrid products.

\section{References}

[1] CEP, R., JANASEK A., PETRU J., CEPOVA L., CZAN A., VALICEK J., (2013) Hard Machinable Machining of Cobalt-based Superalloy, Manufacturing Technology, XIII/13, 2013, 226-231, UJEP: Usti n.

[2] CZÁN, A., SAJGALÍK, M., HOLUBJAK, J., KOURIL, K. (2013) Studying of cutting zone when finishing titanium alloy by application of multifunction measuring syste , In. Manufacturing Technology, 2013, Vol. 13, No. 4, pp. 428-431

[3] CZAN, A., TILlOVA, E., SEMCER, J., PILC, J. (2013) Surface and subsurface residual stresses after machining and their analysis by x-ray diffraction. In. Komunikacie, Volume 15, Issue 2, pp. 69-76

[4] http://dspace.k.utb.cz/bitstream/handle/10563/13084/viselka_2010_dp.pdf?sequence=1 [10.12.2012]

[5] HOLESOVSKY, F., NAPRSTKOVA, N., NOVAK, M., (2012): GICS for grinding process optimization. In Manufacturing Technology XII/12. 2012. UJEP: Ústi n. Labem. p. 22-26. ISSN 1213-2489.

[6] MAŇKOVÁ, I., (2000) Progresívne technológie. Košice: VIENALA, 2000, s. 172 - 233

[7] CUBONOVA, N. Post-processing of CL Data in CAD/CAM System Edgecam using the Constructor of Postprocessors, Manufacturing Technology: J. for Science, Research and Production, vol. 13,

[8] MICHALIK, P., ZAJAC, J., HATALA, M. (2013) Programming CNC machines using computer-aided manufacturing software, Advanced Science Letters Volume 19, Issue 2, February 2013, Pages 369-373, ISSN: 19366612

[9] STANČEKOVÁ, D., ŠEMCER, J, DERBAS, M, KURŇAVA, T. (2013) Methods of measuring of residual stresses and evaluation of residual state of functional surfaces by x-ray diffractometric methods.In: Manufacturing technology. Vol. 13, no. 4 (2013), s. 547-552

[10] PILC, J.- VASILKO, K. (2013) Development and applications of a rotating turning tool. In Manufacturing Technology XIII/13. UJEP: Ústi n. Labem. p. 226-231.

[11] SADÍLEK, M., KRATOCHVÍL, J., PETRŮ, J., ČEP, R., ZLÁMAL, T., STANČEKOVÁ, D. (2014) Cutting tool wear monitoring with the use of impedance layers. In. Tehnicki Vjesnik, Volume 21, 2014, Pages 639-644

[12] DANIŠOVÁ, N., RUŽAROVSKÝ, R., VELÍŠEK, K.(2011) Design alternatives of intelligent camera system for check parts at the intelligent manufacturing-assembly cell. In. ITMS 2011; Shanghai, Applied Mechanics and Materials, 7 Volume pp. 2262-2266 
[13] LUKOVICS, I., BILEK, O., HOLEMY, S. (2010) Aplikace sintrovaneho korundu ve vyrobe naradi. In. Strojirenska technologie XV - 2010/3, s-27-34

[14] LITVAJ, I., PONIŠČIAKOVÁ, O., STANČEKOVÁ, D., DRBÚL, M. (2013) Knowledge processes and their implementation in small transport companies, In: Transport means 2013, Kaunas

[15] NÁPRSTKOVÁ, N., CAIS, J., STANČEKOVÁ, D. (2014) Influence of strontium in AlSi7Mg0.3 alloy on the tool wear, In. Manufacturing Technology, 2014, Vol. 14, No. 1, pp. 75-79,

[16] htpp://www.ferona.cz/cze/katalog/order.phd [13.11.2013]

[17] www.metallograf.de [22.11.2013]

[18] http://www.posterus.sk/?p=12291 [3.10.2012]

\section{Paper number: M201484}

Copyright $\odot$ 2014. Published by Manufacturing Technology. All rights reserved. 